\title{
The effect of sodium nitrite infusion on renal function, brachial and central blood pressure during enzyme inhibition by allopurinol, enalapril or acetazolamide in healthy subjects: a randomized, double- blinded, placebo-controlled, crossover study
}

Jeppe B. Rosenbaek (1D, Erling B. Pedersen(D) and Jesper N. Bech(D)

\begin{abstract}
Background: Sodium nitrite $\left(\mathrm{NaNO}_{2}\right)$ causes vasodilation, presumably by enzymatic conversion to nitric oxide (NO). Several enzymes with nitrite reducing capabilities have been discovered in vitro, but their relative importance in vivo has not been investigated. We aimed to examine the effects of $\mathrm{NaNO}_{2}$ on blood pressure, fractional sodium excretion ( $\mathrm{FE}_{\mathrm{Na}}$ ), free water clearance $\left(\mathrm{C}_{\mathrm{H} 2 \mathrm{O}}\right)$ and $\mathrm{GFR}$, after pre-inhibition of xanthine oxidase, carbonic anhydrase, and angiotensin-converting enzyme. The latter as an approach to upregulate endothelial NO synthase activity.

Methods: In a double-blinded, placebo-controlled, crossover study, 16 healthy subjects were treated, in a randomized order, with placebo, allopurinol $150 \mathrm{mg}$ twice daily (TD), enalapril $5 \mathrm{mg}$ TD, or acetazolamide $250 \mathrm{mg}$ TD. After 4 days of treatment and standardized diet, the subjects were examined at our lab. During intravenous infusion of $240 \mu \mathrm{g}$ $\mathrm{NaNO}_{2} / \mathrm{kg} /$ hour for $2 \mathrm{~h}$, we measured changes in brachial and central blood pressure (BP), plasma cyclic guanosine monophosphate (P-cGMP), plasma and urine osmolality, GFR by ${ }^{51} \mathrm{Cr}$-EDTA clearance, $\mathrm{FE}_{\mathrm{Na}}$ and urinary excretion rate of cGMP (U-cGMP) and nitrite and nitrate $\left(U-N O_{x}\right)$. Subjects were supine and orally water-loaded throughout the examination day.
\end{abstract}

Results: Irrespective of pretreatment, we observed an increase in $\mathrm{FE}_{\mathrm{Na}}$, heart rate, $\mathrm{U}-\mathrm{NO}_{\mathrm{x}}$, and a decrease in $\mathrm{C}_{\mathrm{H} 2 \mathrm{O}}$ and brachial systolic BP during $\mathrm{NaNO}_{2}$ infusion. P-cGMP and U-cGMP did not change during infusion. We observed a consistent trend towards a reduction in central systolic BP, which was only significant after allopurinol.

Conclusion: This study showed a robust BP lowering, natriuretic and anti-aquaretic effect of intravenous $\mathrm{NaNO}_{2}$ regardless of preceding enzyme inhibition. None of the three enzyme inhibitors used convincingly modified the pharmacological effects of $\mathrm{NaNO}_{2}$. The steady cGMP indicates little or no conversion of nitrite to NO. Thus the effect of $\mathrm{NaNO}_{2}$ may not be mediated by $\mathrm{NO}$ generation.

Trial registration: EU Clinical Trials Register, 2013-003404-39. Registered December 32013.

Keywords: Sodium nitrite, Enzyme inhibition, Natriuresis, Aquaresis, Central blood pressure

* Correspondence: jepros@rm.dk
University Clinic in Nephrology and Hypertension, Regional Hospital West
Jutland and Aarhus University, Laegaardvej 12J, DK-7500 Holstebro, Denmark

(c) The Author(s). 2018 Open Access This article is distributed under the terms of the Creative Commons Attribution 4.0 International License (http://creativecommons.org/licenses/by/4.0/), which permits unrestricted use, distribution, and

reproduction in any medium, provided you give appropriate credit to the original author(s) and the source, provide a link to the Creative Commons license, and indicate if changes were made. The Creative Commons Public Domain Dedication waiver (http://creativecommons.org/publicdomain/zero/1.0/) applies to the data made available in this article, unless otherwise stated. 


\section{Background}

Sodium nitrite $\left(\mathrm{NaNO}_{2}\right)$ has a well known vasodilatory effect, which is believed to rely on the enzymatic and non-enzymatic reduction of nitrite to nitric oxide (NO). The generation of NO from endogenous and exogenous nitrite is an alternative and parallel pathway to the classical synthesis of $\mathrm{NO}$ from L-arginine by endothelial NO synthase (eNOS). Several enzymes e.g. xanthine oxidase $(\mathrm{XO})$, carbonic anhydrase (CA), and even eNOS, are reported to possess nitrite reducing capabilities, and hence increasing the bioavailability of NO using nitrite as substrate. Reduction of nitrite to NO occurs preferentially during hypoxia and acidosis, but most of the enzymes retain the ability to generate $\mathrm{NO}$ at physiological conditions, although at a lower rate and requiring higher concentrations of nitrite [1].

The XO inhibitor allopurinol has repeatedly been shown to attenuate the blood pressure (BP) reduction by $\mathrm{NaNO}_{2}$ in rats [2-4]. The effect of XO inhibition was selective to nitrite, as the vasodepressor effect of sodium nitroprusside, another NO donor, was intact in all three studies. Ghosh et al. found an association between nitrite reductase activity in erythrocytic $\mathrm{XO}$ and the efficacy of dietary nitrate to reduce BP in hypertensive patients [4].

Several studies have found favorable changes in NO metabolites during treatment with various inhibitors of angiotensin-converting enzyme (ACE). The mechanism is suggested to be an up-regulation of eNOS, due to an accumulation of bradykinin $[5,6]$. It appears to be a class-effect of ACE inhibitors, as Comini et al. found a consistent increase in rat plasma $\mathrm{NO}_{x}$ (combined nitrate and nitrite), eNOS expression and eNOS activity using a range of ACE inhibitors, including enalapril [7]. In clinical trials, long-term treatments with lisinopril $[8,9]$ and perindopril [10] were found to elevate plasma levels of $\mathrm{NO}_{\mathrm{x}}$ in hypertensive patients. Similarly, injection of quinaprilat in healthy subjects [11] and short-term treatment of normotensive type 1 diabetics with enalapril [12], were shown to enhance endothelial function evaluated by flow-mediated vasodilation.

In vitro studies have shown nitrite reducing effects of $\mathrm{CA}$, and suggest a stimulatory effect of acetazolamide on $\mathrm{NO}$ generation, despite the inhibition of $\mathrm{CO}_{2}$ hydration $[13,14]$. A recent clinical trial found a positive effect of nitrate intake on the increase in visually stimulated cerebral blood flow when injecting acetazolamide in healthy male subjects [15].

The relative significance of the individual nitrite reductases for the bioactivation of $\mathrm{NaNO}_{2}$ in vivo has yet to be determined. In this randomized, double-blind, 4-way crossover study we aimed to investigate the relative importance of $\mathrm{ACE}, \mathrm{XO}$, and $\mathrm{CA}$ for the various effects of $\mathrm{NaNO}_{2}$ under physiological conditions. After preceding enzyme modulation with allopurinol, enalapril, or acetazolamide, we measured the effects of $\mathrm{NaNO}_{2}$ infusion on 1) the central and brachial BP, 2) the renin-angiotensin-aldosterone system 3) plasma and urinary $\mathrm{NO}_{\mathrm{x}}$ and guanosine $3^{\prime}, 5^{\prime}$-cyclic monophosphate (cGMP), and 4) the renal water and sodium regulation. We hypothesized the following: Pretreatment with allopurinol inhibits the ability of $\mathrm{XO}$ to reduce nitrite to bioactive $\mathrm{NO}$ and hence attenuates the effects of $\mathrm{NaNO}_{2}$, while enalapril and acetazolamide, on the contrary, stimulate the generation of NO from nitrite through eNOS and CA respectively, augmenting the effects of $\mathrm{NaNO}_{2}$.

\section{Methods \\ Subjects}

Subjects were recruited by advertisement on local educational institutions. Prior to enrollment, all subjects passed an examination including medical history, physical examination, office BP measurement, urine dipstick, electrocardiography, and the following blood samples: P-cholesterol, P-alkaline phosphatase, P-alanine aminotransferase, P-bilirubin, B-glycated hemoglobin (hemoglobin A1c), P-thyroid-stimulating hormone, P-urate, P-total $\mathrm{CO}_{2}$ in venous blood, P-sodium, P-potassium, P-creatinine, P-albumin, B-platelets, B-leukocytes, B-hemoglobin, and hematocrit.

\section{Inclusion criteria}

Both gender, age $18-40$ years, BMI $18.5-30.0 \mathrm{~kg} / \mathrm{m}^{2}$.

\section{Exclusion criteria}

Alcohol consumption $>14$ drinks per week for women and $>21$ drinks per week for men, smoking, substance abuse, current use of medicine except contraception, known intolerance to the study drugs, office BP $>140$ / 90, diabetes mellitus, anemia, estimated GFR $<60 \mathrm{ml} /$ min (MDRD), history or signs of clinically relevant kidney, heart, liver, lung, neurological, or endocrine diseases, pregnancy or lactation, and blood donation within 1 month of the first investigation.

\section{Withdrawal criteria}

Development of exclusion criteria, serious or unacceptable adverse events, suspicion of poor compliance to study medication, sustained $\mathrm{BP}<90 / 50$ or symptoms of low $\mathrm{BP}$ during $\mathrm{NaNO}_{2}$ infusion.

\section{Design}

The study was conducted as a double-blinded, placebocontrolled, 4-way crossover trial. Subjects received allopurinol, enalapril, acetazolamide, or placebo for 4 days in random order. Each treatment period was followed by an examination day. The examination days were separated by a wash-out period of at least 3 weeks. 


\section{Study drugs}

Allopurinol (Tablet Allopurinol "DAK", $300 \mathrm{mg}$ ) was produced by Takeda Pharma A/S, Taastrup, Denmark. Enalapril (Tablet Enalapril "Actavis", $5 \mathrm{mg}$ ) was produced by Actavis Nordic A/S, Gentofte, Denmark. Acetazolamide (Tablet Diamox, $250 \mathrm{mg}$ ) was produced by Goldshield Pharmaceuticals Limited, Surrey, United Kingdom. Placebo contained $120 \mathrm{mg}$ of potato starch and $51 \mathrm{mg}$ lactose monohydrate. All tablets were covered in opaque gelatine capsules and were identical in appearance. Sodium nitrite $10 \mathrm{mg} / \mathrm{ml}$ (Skanderborg Pharmacy, Denmark) was diluted in isotonic saline immediately before administration according to subject weight.

\section{Randomization}

Treatment order was allocated consecutively at the time of inclusion by the principal investigator according to a randomization plan created on randomization.com by the Hospital Pharmacy, Central Denmark Region. Medication was packed, sealed and labeled by the Hospital Pharmacy. Investigators, lab technicians, and subjects were blinded to treatment order for the duration of the trial.

\section{Number of subjects}

Using a power of $80 \%$ and a significance level of $5 \%$ the minimum number of subjects should be 14 when the minimum relevant relative change in fractional sodium excretion $\left(\mathrm{FE}_{\mathrm{Na}}\right)$ is $10 \%$, and the standard deviation is $12 \%$. Due to expected dropouts and incomplete voiding, the minimum number of included subjects was set to 20 .

\section{Experimental procedure Before examination}

For 4 days prior to each examination day, subjects ingested a standard diet prepared by the hospital kitchen. One of two diet sizes, $11.000 \mathrm{~kJ}$ per day or $15.000 \mathrm{~kJ}$ per day, was chosen according to the estimated energy demands for each subject based on weight and physical activity. Regardless of diet size, the nutritional composition was $55 \%$ carbohydrates, $30 \%$ fat, and $15 \%$ protein, sodium content was $135 \mathrm{mmol}$ per day and content of nitrate and nitrite was minimized. Subjects were asked to drink $2.5 \mathrm{~L}$ daily, including a maximum of two small cups of coffee or tea. No alcohol or soft drinks were allowed. The subjects were asked to take the study medication twice daily (TD) between 7-8 AM and 6$8 \mathrm{PM}$, with the last dose on the morning of the examination day. Dosage: Allopurinol: $150 \mathrm{mg}$ TD, enalapril: $5 \mathrm{mg}$ TD, acetazolamide: $250 \mathrm{mg}$ TD.

\section{Examination day}

On each examination day, the subjects arrived at the lab at 7.45 AM after an overnight fast, bringing a 24-h urine collection. Two indwelling catheters were placed in antecubital veins, one for sequential blood samples and one in the opposite arm for the administration of chromium-51 labeled ethylenediamine tetraacetic acid $\left({ }^{51} \mathrm{Cr}\right.$-EDTA $)$ and $\mathrm{NaNO}_{2}$. An oral load of $175 \mathrm{ml}$ of tap water every half hour was started at 7.30 AM with the last dose of study medication. The subjects were installed in supine position in a quiet, temperature-controlled $\left(22-25{ }^{\circ} \mathrm{C}\right)$ room throughout the day. Voiding was done sitting or standing. After 90 min of adaptation, blood and urine samples were collected every $30 \mathrm{~min}$ from $9.30 \mathrm{AM}$ to $1.30 \mathrm{PM}$. The first two clearance periods were used as baseline. The baseline periods were followed by four periods from 10.30 AM to $12.30 \mathrm{PM}$, during which a sustained infusion of $50 \mathrm{ml}$ saline diluted $\mathrm{NaNO}_{2}$, $240 \mu \mathrm{g} / \mathrm{kg} / \mathrm{hour}(=3.48 \mu \mathrm{mol} / \mathrm{kg} / \mathrm{hour})$, was administered, and finally two post-infusion periods from 12.30 PM to 1.30 PM. Blood samples were analyzed for ${ }^{51} \mathrm{Cr}$-EDTA, P-sodium, and P-osmolality (P-Osm). The sample at $1.30 \mathrm{PM}$ was analyzed for combined nitrite and nitrate $\left(\mathrm{P}-\mathrm{NO}_{\mathrm{x}}\right)$ and the samples at 10.30 AM, 11.30 AM and 12.30 PM also for plasma concentrations of renin (PRC), arginine vasopressin (P-AVP), angiotensin II (P-ANGII), P-aldosterone, P-cGMP, P-urate and plasma total carbon dioxide in venous blood $\left(\mathrm{P}-(\mathrm{vB})\right.$-total $\left.\mathrm{CO}_{2}\right)$. The sample volume was replaced 1:1 with isotonic saline. Urine samples were analyzed for sodium, creatinine, osmolality (U-Osm), ${ }^{51} \mathrm{Cr}$-EDTA, $\gamma$-subunit of the epithelial sodium channel (U-ENaCY), and aquaporin-2 (U-AQP2). Samples at 10.30 AM, 11.30 AM, 12.30 PM and 1.30 PM were furthermore analyzed for U-cGMP and $\mathrm{U}-\mathrm{NO}_{\mathrm{x}}$.

\section{Blood pressure measurements}

Brachial blood pressure was measured oscillometrically using Omron 705IT (Omron Healthcare Co. Ltd., Kyoto, Japan) every $15 \mathrm{~min}$. Central systolic blood pressure (CSBP) was estimated by tonometric pulse wave analysis HealthSTATS BPro (HealthSTATS International, Singapore). The device was applied and calibrated according to the directions of the manufacturer, using the averaged last three of four consecutive measurements with the Omron 705IT. Sequential measurements were made every 15 min from 9 AM to 1.30 PM.

\section{Renal function}

Glomerular filtration rate (GFR) was measured by the constant infusion clearance technique with ${ }^{51} \mathrm{Cr}$-EDTA as reference substance [16]. 


\section{Biochemical analyses}

Blood samples were drawn from an indwelling catheter, placed in ice water and centrifuged immediately at $2200 \mathrm{G}$ for $10 \mathrm{~min}$ at $4{ }^{\circ} \mathrm{C}$. Immediately after voiding, urine was centrifuged at $2200 \mathrm{G}$ for $10 \mathrm{~min}$ at $4{ }^{\circ} \mathrm{C}$. Concentrations of sodium, potassium, and creatinine were measured using routine methods at the Department of Clinical Biochemistry, Regional Hospital West Jutland, Denmark. Urine supernatant and plasma were kept frozen in cryotubes at $-80{ }^{\circ} \mathrm{C}$ (PRC, P-aldosterone, P-AVP, and combined nitrate and nitrite $\left(\mathrm{P}-\mathrm{NO}_{\mathrm{x}}\right.$ and $\left.\mathrm{U}-\mathrm{NO}_{\mathrm{x}}\right)$ ), or at $-20{ }^{\circ} \mathrm{C}$ (P-ANGII, P-cGMP, U-cGMP, U-ENaC $\gamma$, U-AQP2, P-Osm, and U-Osm) until assayed.

P-AVP and P-ANGII were extracted from plasma with $\mathrm{C}_{18}$ Sep-Pak (Waters Corporation, Milford, MA, USA) and determined by radioimmunoassay (RIA) as previously described $[16,17]$. The antibodies against AVP were a gift from Professor Jacques Dürr (Miami, FL, USA). Minimal detection level: $0.5 \mathrm{pmol} / \mathrm{L}$. Coefficients of variation: $13 \%$ (inter-assay) and 9\% (intra-assay). Antibodies against ANGII were obtained from the Department of Clinical Physiology, Glostrup Hospital, Denmark. Minimal detection level: $2 \mathrm{pmol} / \mathrm{L}$. Coefficients of variation: 12\% (inter-assay) and $8 \%$ (intra-assay).

P-Aldosterone was determined by RIA (Demeditec Diagnostics GmbH, Kiel, Germany). The minimal detection level was $3.99 \mathrm{pmol} / \mathrm{L}$. The coefficients of variations were $17.2 \%$ (inter-assay) and $12.6 \%$ (intra-assay).

Plasma renin concentration (PRC) was determined by a RIA kit from Cisbio Bioassays, Codolet, France. The minimal detection level: $1 \mathrm{pg} / \mathrm{ml}$. Coefficients of variation in the range $4-263 \mathrm{pg} / \mathrm{ml}: 3.6-5.0 \%$ (interassay) and $0.9-3.6 \%$ (intra-assay).

Plasma and urine osmolality was determined by freeze-point depression $\left(\mathrm{A}_{2} \mathrm{O}\right.$ Advanced Automated Osmometer, Advanced Instruments, MA, USA).

$\mathrm{U}-\mathrm{NO}_{\mathrm{x}}$ and $\mathrm{P}-\mathrm{NO}_{\mathrm{x}}$ were determined by a colorimetric assay (R\&D Systems, Minneapolis, MN, USA). Nitrate was reduced to nitrite by nitrate reductase and subsequently converted to a deep purple azo compound by addition of Griess reagent. The concentration was determined by photometric measurement of absorbance at $540 \mathrm{~nm}$. Minimal detection level in urine: $15.6 \mu \mathrm{mol} / \mathrm{L}$ and in plasma: $6.2 \mu \mathrm{mol} / \mathrm{L}$. The coefficients of variation were $3.9 \%$ (inter-assay) and $1.8 \%$ (intra-assay).

U-cGMP and P-cGMP were determined by a competitive enzyme immunoassay kit from R\&D Systems, Minneapolis, MN, USA. Minimal detection level: $1.14 \mathrm{pmol} /$ L. Coefficients of variation: 6.9\% (inter-assay) and 4.9\% (intra-assay).

U-AQP2 was determined by RIA as previously described $[18,19]$. Rabbit anti-AQP2 antibodies were a gift from Professor Soren Nielsen and Professor Robert Fenton, The Water and Salt Research Center, Aarhus
University, Denmark. Minimal detection level: $32 \mathrm{pg} /$ tube. Coefficients of variation: $11.7 \%$ (inter-assay) and $5.9 \%$ (intra-assay).

$\mathrm{U}-\mathrm{ENaC} \gamma$ was measured by RIA as previously described [20]. ENaC $\gamma$ was synthesized and purchased by Lofstrand, Gaithersburg, Maryland, USA. The ENaCY antibodies were a gift from Professor Soren Nielsen and Professor Robert Fenton, The Water and Salt Research Center, Aarhus University. It was raised against a synthetic peptide in rabbits, and affinity purified as previously described [21].

\section{Calculations}

$\mathrm{FE}_{\mathrm{Na}}$ was calculated using the formula (sodium clearance $\left(\mathrm{C}_{\mathrm{Na}}\right) /{ }^{51} \mathrm{Cr}$-EDTA clearance $\left.\times 100 \%\right) . \mathrm{C}_{\mathrm{Na}}$ was calculated as (U-Na / P-Na x urine output rate (UOR)). Free water clearance $\left(\mathrm{C}_{\mathrm{H} 2 \mathrm{O}}\right)$ was calculated as $(\mathrm{UOR}$ - osmolar clearance $\left.\left(\mathrm{C}_{\mathrm{osm}}\right)\right)$. $\mathrm{C}_{\mathrm{osm}}$ was calculated as (U-osmolality / P-osmolality $\mathrm{x}$ UOR). Creatinine clearance was calculated for 24-h urine as (urine volume $\mathrm{x}$ $\mathrm{U}$-creatinine) / (P-creatinine $\mathrm{x}$ urine collection period).

\section{Statistical analysis}

Statistical tests were performed in SPSS Statistics ver. 20 (IBM Corp., Armonk, NY, USA). All data was graphically evaluated for normality using Q-Q plots. Where logarithmic transformation could correct skewed data, parametric tests were performed on the transformed data. Statistics were performed using one-way repeated measures (RM) ANOVA for comparing over time within each pretreatment. A two-way RM ANOVA with time and pretreatment as within factors were used to test for interaction between pretreatment and time. Comparisons between placebo and pretreatments at baseline or between baseline and individual time points within groups were performed using paired $t$-test. When skewed data could not be normalized by log transformation, Friedman test and Wilcoxon signed-rank test were performed instead. Normal distributed data are presented as means with 95\% confidence intervals, and non-parametric data as medians with inter-quartile ranges in brackets. Statistical significance was defined as $p<0.05$. Pairwise comparisons with baseline were Bonferroni corrected.

\section{Results}

\section{Demographics}

A total of 25 subjects were assessed for eligibility. Four were excluded due to elevated blood pressure (1), microscopic hematuria (1), elevated liver enzymes (1), and withdrawal of consent (1) prior to participation. During the study, five more dropped out, due to dizziness (1), headache (1), inability to void according to schedule (1), trouble placing intravenous catheters (1), and withdrawal 
of consent due to personal bustle (1) (Fig. 1). The remaining 16 completed the study; characteristics are presented in Table 1. Two was excluded from the urine analyses due to incomplete voiding during examination days.

\section{Effect of pretreatment on baseline characteristics}

As shown in Table 2, pretreatment with acetazolamide reduced creatinine clearance, absolute sodium excretion, and $\mathrm{P}$-potassium, and increased fractional excretion of potassium $\left(\mathrm{FE}_{\mathrm{K}}\right)$ measured in 24-h urine. It decreased plasma total $\mathrm{CO}_{2}$ in venous blood and marginally increased P-urate. Pretreatment with allopurinol reduced P-urate, and slightly increased 24-h excretion of ENaC $\gamma$, while enalapril marginally increased 24-h excretion of albumin and slightly reduced P-sodium.

\section{Effect of $\mathrm{NaNO}_{2}$ on $\mathrm{NO}_{x}$ and cGMP}

We measured a steady increase in $\mathrm{P}-\mathrm{NO}_{\mathrm{x}}$ and $\mathrm{U}-\mathrm{NO}_{\mathrm{x}}$ throughout the $\mathrm{NaNO}_{2}$ infusion, regardless of preceding enzyme inhibition. P-cGMP was unchanged during infusion after all pretreatments. U-cGMP did not change during the infusion ( $p>0.05$ vs. baseline) but decreased significantly in the post-infusion period (Table 3 ).

\section{Effect of $\mathrm{NaNO}_{2}$ on GFR and renal sodium and water excretion}

As shown in Table 4, baseline GFR was significantly lower after acetazolamide compared to placebo $(p<$ 0.001 ), while enalapril and allopurinol did not change baseline GFR. Infusion of $\mathrm{NaNO}_{2}$ did not alter GFR besides transient fluctuations after placebo and acetazolamide. The baseline reduction of GFR after acetazolamide was sustained throughout the examination day. None of the pretreatments changed baseline fractional sodium excretion $\left(\mathrm{FE}_{\mathrm{Na}}\right)$ compared to placebo. During $\mathrm{NaNO}_{2}$ infusion, $\mathrm{FE}_{\mathrm{Na}}$ increased regardless of

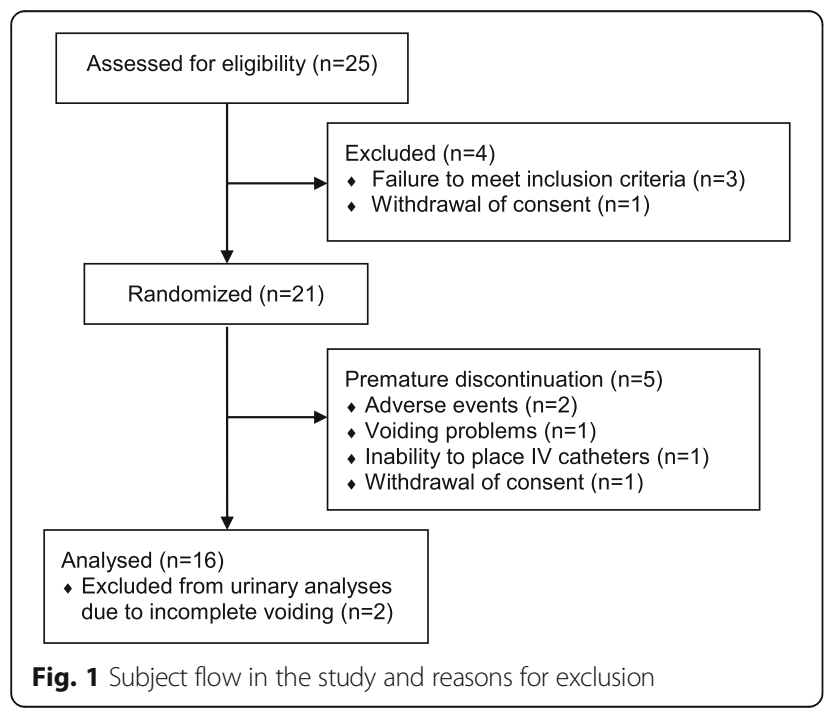

Table 1 Clinical and laboratory characteristics of the 16 subjects

\begin{tabular}{|c|c|}
\hline Gender (male/female) & $5 / 11$ \\
\hline Age (years) & $23[19 ; 27]$ \\
\hline $\mathrm{BMI}\left(\mathrm{kg} / \mathrm{m}^{2}\right)$ & $23[20 ; 29]$ \\
\hline Systolic blood pressure $(\mathrm{mmHg})$ & $121[111 ; 132]$ \\
\hline Diastolic blood pressure $(\mathrm{mmHg})$ & $73[64 ; 87]$ \\
\hline P-alanine aminotransferase (U/I) & $23(16 ; 28)$ \\
\hline P-bilirubin $(\mu \mathrm{mol} / \mathrm{l})$ & $8.0(6.3 ; 10.0)$ \\
\hline P-alkaline phosphatase $(\mathrm{U} / \mathrm{l})$ & $57(44 ; 82)$ \\
\hline P-cholesterol (mmol/l) & $4.2[3.7 ; 4.8]$ \\
\hline B-glycated hemoglobin (mmol/mol) & $34(32 ; 35)$ \\
\hline P-thyroid stimulating hormone (mIE/l) & $1.17(0.78 ; 2.05$ \\
\hline P-urate $(\mathrm{mmol} / \mathrm{l})$ & $26[22 ; 30]$ \\
\hline P-total $\mathrm{CO}_{2}$ in venous blood $(\mathrm{mmol} / \mathrm{l})$ & $27[26 ; 28]$ \\
\hline P-sodium (mmol/l) & $140[139 ; 141]$ \\
\hline P-potassium (mmol/l) & $3.8[3.7 ; 3.9]$ \\
\hline $\mathrm{eGFR}_{\mathrm{MDRD}}\left(\mathrm{ml} / \mathrm{min} / 1.73 \mathrm{~m}^{2}\right)$ & $100[92 ; 107]$ \\
\hline P-albumin (g/l) & $42[40 ; 43]$ \\
\hline B-platelets $\left(\times 10^{9} / \mathrm{l}\right)$ & $233[208 ; 259]$ \\
\hline B-leukocytes $\left(\times 10^{9} / 1\right)$ & $6.3[5.3 ; 7.3]$ \\
\hline B-hemoglobin ( $\mathrm{mmol} / \mathrm{l})$ & $8.6[8.2 ; 9.0]$ \\
\hline Hematocrit & $.40[.42 ; 44]$ \\
\hline
\end{tabular}

Normal distributed data are presented as means with $95 \%$ confidence interval in brackets and non-parametric data as medians with 25th and 75th percentiles

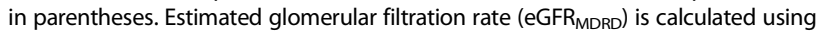
the Modification of Diet in Renal Disease Study equation

pretreatment. Urinary sodium excretion increased in a similar way as $\mathrm{FE}_{\mathrm{Na}}$ (data not presented). Excretion rate of $\mathrm{ENaC \gamma}$ was significantly higher at baseline and during $\mathrm{NaNO}_{2}$ infusion after acetazolamide, while the median level of excretion rate did not change consistently during infusion after any of the pretreatments.

At baseline, there was no significant difference in $\mathrm{C}_{\mathrm{H} 2 \mathrm{O}}$, or urine output (UO, not presented) between the pretreatments. During and after $\mathrm{NaNO}_{2}$ infusion, we observed a decrease in $\mathrm{C}_{\mathrm{H} 2 \mathrm{O}}$ and $\mathrm{UO}$ (not presented), with the maximum effect after 60-90 min. This response was not modified by any of the pretreatments. At baseline, U-AQP2 was significantly higher after allopurinol, while there was no difference in P-AVP regardless of pretreatment. In response to $\mathrm{NaNO}_{2}$, we observed a significant decrease in P-AVP on the placebo day. The reduction was insignificant after allopurinol, enalapril, and acetazolamide. We could not detect significant changes in U-AQP2 in response to $\mathrm{NaNO}_{2}$, neither after placebo nor after preceding enzyme inhibition.

\section{Effect of $\mathrm{NaNO}_{2}$ on blood pressure}

As shown in Table 5, brachial systolic BP was decreased, and heart rate increased during $\mathrm{NaNO}_{2}$ infusion 
Table 2 Effect of allopurinol, enalapril and acetazolamide on 24-h urine collection and selected baseline blood samples

\begin{tabular}{|c|c|c|c|c|c|}
\hline & Placebo & Allopurinol & Enalapril & Acetazolamide & $\mathrm{P}_{\mathrm{RM}}$ ANOVA/Friedman \\
\hline $\mathrm{CrCl}\left(\mathrm{ml} / \mathrm{min} / 1.73 \mathrm{~m}^{2}\right)$ & $134[120 ; 148]$ & $137[124 ; 150]$ & $130[117 ; 142]$ & $116[103 ; 130]^{*}$ & .030 \\
\hline Urine output (ml/min) & $1.77[1.42 ; 2.12]$ & $1.71[1.38 ; 2.03]$ & $1.58[1.20 ; 1.96]$ & $1.78[1.48 ; 2.08]$ & .411 \\
\hline $\mathrm{C}_{\mathrm{H} 2 \mathrm{O}}(\mathrm{ml} / \mathrm{min})$ & $-0.32[-0.62 ;-0.01]$ & $-0.43[-0.68 ;-0.17]$ & $-0.36[-0.71 ; 0.00]$ & $-0.19[-0.49 ; 0.10]$ & .304 \\
\hline P-sodium (mmol/l) & $139[138 ; 139]$ & $138[137 ; 139]$ & $137[137 ; 138]^{*}$ & $138[137 ; 139]$ & .025 \\
\hline U-Na (mmol/24 h) & $129[107 ; 151]$ & $135[115 ; 154]$ & $116[98 ; 134]$ & $101[80 ; 122]^{*}$ & .034 \\
\hline $\mathrm{FE}_{\mathrm{Na}}(\%)$ & $0.47[0.40 ; 0.54]$ & $0.49[0.39 ; 0.60]$ & $0.45[0.38 ; 0.52]$ & $0.42[0.35 ; 0.50]$ & .412 \\
\hline P-potassium (mmol/l) & $4.1[4.0 ; 4.1]$ & $4.0[3.9 ; 4.1]$ & $4.1[4.0 ; 4.2]$ & $3.6[3.6 ; 3.7]^{*}$ & $<.001$ \\
\hline U-K (mmol/24 h) & $57.8(45.9 ; 75.8)$ & $59.2(41.3 ; 72.1)$ & $51.9(42.5 ; 83.0)$ & $76.3(52.7 ; 95.1)$ & .349 \\
\hline$F E_{K}(\%)$ & $7.91[6.71 ; 9.11]$ & $7.55[6.17 ; 8.92]$ & $7.67[6.48 ; 8.85]$ & $11.6[9.84 ; 13.4]^{*}$ & $<.001$ \\
\hline U-albumin (mg/24 h) & $2.98(1.25 ; 4.75)$ & $2.02(1.00 ; 4.00)$ & $4.50(1.32 ; 8.25)^{*}$ & $3.00(2.25 ; 4.75)$ & .184 \\
\hline U-AQP2 (ng/min) & $0.51(0.41 ; 0.76)$ & $0.64(0.46 ; 0.83)$ & $0.62(0.42 ; 0.92)$ & $0.50(0.38 ; 0.62)$ & .071 \\
\hline $\mathrm{U}-\mathrm{ENaCY}(\mathrm{ng} / \mathrm{min})$ & $0.23(0.21 ; 0.31)$ & $0.28(0.23 ; 0.34)^{*}$ & $0.27(0.23 ; 0.36)$ & $0.30(0.24 ; 0.38)$ & .091 \\
\hline P-urate (mmol/l) & $0.29[0.25 ; 0.33]$ & $0.16[0.13 ; 0.20]^{*}$ & $0.29[0.25 ; 0.33]$ & $0.34[0.30 ; 0.38]^{*}$ & $<.001$ \\
\hline P-(vB)-total $\mathrm{CO}_{2}(\mathrm{mmol} / \mathrm{l})$ & $25.1[23.9 ; 26.4]$ & $25.0[24.0 ; 26.0]$ & $24.4[23.7 ; 25.1]$ & $18.4[17.4 ; 19.3]^{*}$ & $<.001$ \\
\hline
\end{tabular}

Effect of 4 days treatment with allopurinol, enalapril and acetazolamide on 24-h urine collection and selected baseline blood samples in 16 healthy subjects. Creatinine clearance $(\mathrm{CrCl})$, urine output, free water clearance $\left(\mathrm{C}_{\mathrm{H} 2 \mathrm{O}}\right)$, urinary excretion rate of sodium (U-Na) and potassium $(\mathrm{U}-\mathrm{K})$ and fractional excretion of sodium $\left(\mathrm{FE}_{\mathrm{Na}}\right)$ and potassium $\left(\mathrm{FE}_{\mathrm{K}}\right)$, urinary excretion rate of albumin, aquaporin-2 (U-AQP2), and $\gamma$-subunit of the epithelial sodium channel $(\mathrm{U}-\mathrm{ENaC} \mathrm{Y})$, plasma sodium ( $\mathrm{P}-\mathrm{Na})$, potassium $(\mathrm{P}-\mathrm{K})$, urate, and total carbon dioxide in venous blood ( $\mathrm{P}-(\mathrm{VB})$-total $\left.\mathrm{CO}_{2}\right)$. Normal distributed data are presented as means with $95 \%$ confidence interval in brackets, and non-parametric data as medians with 25 th and 75 th percentiles in parentheses. Statistics were performed using one-way repeated measures (RM) ANOVA or Friedman test (U-albumin, U-AQP2, U-ENaCY). U-K was log transformed before RM ANOVA. Pairwise comparison with placebo was performed using Student's $t$-test or Wilcoxon signed-rank test (U-albumin, U-AQP2, U-ENaC $\gamma$ )

Statistically significantly different from placebo: ${ }^{*}=p<.05$

regardless of pretreatment. The reduction in brachial diastolic BP was only significant after acetazolamide $(p$ $=0.035$ ). Brachial mean arterial pressure (MAP) was significantly reduced in response to $\mathrm{NaNO}_{2}$ infusion regardless of pretreatment. There was a trend to a reduction in central systolic $\mathrm{BP}$, which was only significant after allopurinol $(p=0.047)$.

\section{Effect of $\mathrm{NaNO}_{2}$ on the renin-angiotensin-aldosterone system (RAAS)}

As depicted in Table 6, PRC was clearly increased at baseline after pretreatment with enalapril, and to a lesser extent after acetazolamide, compared to placebo. In response to $\mathrm{NaNO}_{2}$ infusion, PRC increased further after both enalapril and acetazolamide. Compared to placebo, angiotensin II (AngII) was decreased at baseline after enalapril and allopurinol. In response to $\mathrm{NaNO}_{2}$ infusion, AngII increased marginally only after acetazolamide. Aldosterone was increased at baseline after acetazolamide compared to placebo. The baseline suppression after enalapril was insignificant compared to placebo $(p=0.079)$. $\mathrm{NaNO}_{2}$ infusion did not affect aldosterone levels after any of the pretreatments.

\section{Safety}

We observed 26 adverse events, predominantly expected side effects such as paresthesia after acetazolamide (7), gastrointestinal discomfort after enalapril (5), headache (8), and lightheadedness (3) including one event of micturition syncope. None of the adverse events were considered serious.

\section{Discussion}

In the present study, our aim was to investigate the impact of preceding short-term modulation of three different enzyme systems on the various acute effects of sodium nitrite infusion. Without active pretreatment, we found that intravenous $\mathrm{NaNO}_{2}$ led to an increased natriuresis, an increase in $\mathrm{P}-\mathrm{NO}_{\mathrm{x}}$ and $\mathrm{U}-\mathrm{NO}_{\mathrm{x}}$, a small decrease in AVP, and a systolic BP reduction, along with a decreased aquaresis, an unaffected P-cGMP and even a reduction in U-cGMP in the post-infusion period. Preceding enzyme inhibition did not convincingly modify the effects.

The decrease we observed in brachial BP is in agreement with other studies using comparable doses [2224]. However, this reduction is smaller than in a recent dose-response study, where our group in addition to a larger decrease in brachial systolic and mean arterial BP found a significant reduction in both the brachial diastolic and the central systolic BP using the same dose of $\mathrm{NaNO}_{2}$ [25]. The reason for this discrepancy might be the different gender ratio in the two studies; the percentage of females was $69 \%$ in the present study compared to $42 \%$ in the dose-response study. While no gender difference has been reported for $\mathrm{NaNO}_{2}$, Kapil et al. found a substantially greater reduction in both systolic and 
Table 3 Effect of intravenous $\mathrm{NaNO}_{2}$ on combined nitrate and nitrite (NOx) and cGMP

\begin{tabular}{|c|c|c|c|c|c|}
\hline & \multirow[t]{2}{*}{ Baseline } & \multicolumn{2}{|l|}{ Infusion } & \multirow{2}{*}{$\begin{array}{l}\text { Post-infusion } \\
180 \text { min }\end{array}$} & \multirow{2}{*}{$\begin{array}{l}p_{\text {RM }} \\
\text { ANOVA } \\
\text { (one-way) }\end{array}$} \\
\hline & & $60 \min$ & $120 \mathrm{~min}$ & & \\
\hline \multicolumn{6}{|l|}{$\mathrm{P}-\mathrm{NO}_{\mathrm{x}}(\mu \mathrm{mol} / \mathrm{l})$} \\
\hline Placebo & $17(13 ; 21)$ & $25(19 ; 31)^{*}$ & $31(24 ; 38)^{*}$ & $29(22 ; 35)^{*}$ & $<.001$ \\
\hline Allopurinol & $17(14 ; 23)$ & $24(19 ; 30)^{*}$ & $32(26 ; 36)^{*}$ & $30(26 ; 32)^{*}$ & $<.001$ \\
\hline Enalapril & $15(12 ; 19)$ & $24(21 ; 31)^{*}$ & $29(26 ; 32)^{*}$ & $27(24 ; 31)^{*}$ & $<.001$ \\
\hline Acetazolamide & $17(13 ; 19)$ & $24(21 ; 31)^{*}$ & $30(27 ; 35)^{*}$ & $27(23 ; 32)^{*}$ & $<.001$ \\
\hline \multicolumn{2}{|c|}{$p_{\text {interaction (pretreatment } x \text { time) }}$} & \multicolumn{2}{|c|}{.742} & & \\
\hline \multicolumn{6}{|l|}{$\mathrm{U}-\mathrm{NO}_{x}(\mu \mathrm{mol} / \mathrm{min})$} \\
\hline Placebo & $0.52(0.37 ; 0.69)$ & $0.72(0.52 ; 0.79)^{*}$ & $0.94(0.88 ; 1.09)^{*}$ & $0.95(0.83 ; 1.21)^{*}$ & $<.001$ \\
\hline Allopurinol & $0.60(0.42 ; 0.88)$ & $0.79(0.65 ; 0.98)^{*}$ & $0.99(0.87 ; 1.23)^{*}$ & $1.07(0.90 ; 1.18)^{*}$ & $<.001$ \\
\hline Enalapril & $0.57(0.44 ; 0.78)$ & $0.69(0.59 ; 0.97)^{*}$ & $0.99(0.87 ; 1.22)^{*}$ & $0.94(0.80 ; 1.31)^{*}$ & $<.001$ \\
\hline Acetazolamide & $0.49(0.45 ; 0.54)$ & $0.63(0.59 ; 0.67)^{*}$ & $0.98(0.86 ; 1.05)^{*}$ & $0.94(0.85 ; 1.06)^{*}$ & $<.001$ \\
\hline \multicolumn{2}{|c|}{$p_{\text {interaction (pretreatment } x \text { time) }}$} & \multicolumn{2}{|c|}{.677} & & \\
\hline \multicolumn{6}{|l|}{ P-cGMP (pmol/ml) } \\
\hline Placebo & $88[78 ; 98]$ & $93[83 ; 104]$ & $87[78 ; 95]$ & & .310 \\
\hline Allopurinol & $91[83 ; 100]$ & $87[77 ; 98]$ & $88[77 ; 98]$ & & .597 \\
\hline Enalapril & $82[71 ; 92]$ & $85[74 ; 96]$ & $93[75 ; 110]$ & & .102 \\
\hline Acetazolamide & $90[78 ; 101]$ & $84[74 ; 93]$ & $84[74 ; 94]$ & & .088 \\
\hline \multicolumn{2}{|c|}{$p_{\text {interaction (pretreatment } x \text { time) }}$} & \multicolumn{2}{|c|}{.111} & & \\
\hline \multicolumn{6}{|c|}{ U-cGMP (pmol/min) } \\
\hline Placebo & $425(356 ; 530)$ & $426(371 ; 561)$ & $414(341 ; 515)$ & $321(235 ; 343)^{*}$ & $<.001$ \\
\hline Allopurinol & $487(388 ; 613)$ & $453(353 ; 575)$ & $461(376 ; 570)$ & $367(287 ; 443)^{*}$ & $<.001$ \\
\hline Enalapril & $404(291 ; 527)^{\dagger}$ & $425(329 ; 552)$ & $409(309 ; 486)$ & $284(243 ; 349)^{*}$ & $<.001$ \\
\hline Acetazolamide & $361(305 ; 484)^{\dagger}$ & $345(296 ; 468)$ & $372(325 ; 470)$ & $269(236 ; 324)^{*}$ & $<.001$ \\
\hline \multicolumn{2}{|c|}{$p_{\text {interaction (pretreatment } x \text { time) }}$} & \multicolumn{2}{|c|}{.362} & & \\
\hline
\end{tabular}

Effect of intravenous $\mathrm{NaNO}_{2}$ on plasma concentrations $(n=16)$ and urinary excretion rates $(n=14)$ of combined nitrate and nitrite $\left(\mathrm{NO}_{x}\right)$ and guanosine $3^{\prime}, 5^{\prime}$-cyclic monophosphate (cGMP) in healthy subjects after 4 days pretreatment with allopurinol, enalapril, acetazolamide, or placebo. Normal distributed data are presented as means with $95 \%$ confidence interval in brackets and non-parametric data as medians with 25 th and 75 th percentiles in parentheses. Statistics were performed using one-way repeated measures (RM) ANOVA for comparing over time and two-way RM ANOVA with time and pretreatment as within factors to test for interaction. Pairwise comparison where performed using Student's $t$-test. $\mathrm{P}-\mathrm{NO}_{x}, \mathrm{U}-\mathrm{NO}_{\mathrm{x}}$ and U-cGMP were log transformed prior to testing

${ }^{*} p<.05$ within group vs. baseline (Bonferroni), ${ }^{\dagger} p<.05$ vs. placebo at baseline

diastolic brachial BP in males compared to females when ingesting potassium nitrate [26].

We observed an increase in both fractional and absolute sodium excretion during $\mathrm{NaNO}_{2}$ infusion. Although there is not complete agreement on the effects of NO in different nephron segments, a net natriuretic and diuretic effect of NO in vivo is commonly accepted [27]. The natriuretic effect we observed during $\mathrm{NaNO}_{2}$ infusion is in agreement with existing data regarding the overall inhibitory effect of NO on sodium absorption in the nephron. However, we found a reduction in free water clearance and urine output (data not presented), which conflicts with the general notion of $\mathrm{NO}$ as a diuretic. A possible explanation could be the reduction in BP. The decrease in P-AVP and steady U-AQP2 suggests that the mechanism is not mediated by AQP2.
Soluble guanylyl cyclase (sGC) releases cGMP to the circulation upon stimulation by NO. Being a renowned second messenger for NO, cGMP is widely used as a surrogate marker of NO activity [28-30]. The lack of increase in P-cGMP and the post-infusion decline in U-cGMP in the present study is puzzling. The findings are nevertheless in agreement with a recent dose-response study from our group [25]. Accordingly, Omar et al. found that an accumulated intra-arterial infusion of approximately $100 \mathrm{mg}$ of $\mathrm{NaNO}_{2}$ did not increase systemic cGMP, measured in the contralateral arm, despite a substantial increase in regional cGMP formation and an $11 \mathrm{mmHg}$ reduction in MAP [31]. In comparison, the accumulated dose used in the present study was approximately $32 \mathrm{mg}$ for the average subject weighing $67 \mathrm{~kg}$. 
Table 4 Effect of intravenous $\mathrm{NaNO}_{2}$ on renal sodium and water regulation

\begin{tabular}{|c|c|c|c|c|c|c|c|c|}
\hline & \multirow[t]{2}{*}{ Baseline } & \multicolumn{4}{|c|}{ Infusion } & \multicolumn{2}{|c|}{ Post-infusion } & \multirow{2}{*}{$\begin{array}{c}p \\
\text { Friedman } \\
\text { RM } \\
\text { ANOVA } \\
\text { (one-way) }\end{array}$} \\
\hline & & $30 \mathrm{~min}$ & $60 \mathrm{~min}$ & $90 \mathrm{~min}$ & $120 \mathrm{~min}$ & $150 \mathrm{~min}$ & $180 \mathrm{~min}$ & \\
\hline \multicolumn{9}{|l|}{$\mathrm{FE}_{\mathrm{Na}}(\%)$} \\
\hline Placebo & $1.26[1.05 ; 1.47]$ & $1.26[1.09 ; 1.43]$ & $1.43[1.25 ; 1.62]$ & $1.38[1.24 ; 1.52]$ & $1.57[1.36 ; 1.78]$ & $1.53[1.34 ; 1.73]$ & $1.41[1.26 ; 1.56]$ & .001 \\
\hline Allopurinol & $1.36[0.96 ; 1.75]$ & $1.41[1.05 ; 1.76]$ & $1.52[1.20 ; 1.83]$ & $1.53[1.22 ; 1.83]$ & $1.66[1.32 ; 2.00]^{*}$ & $1.69[1.40 ; 1.98]^{*}$ & $1.59[1.33 ; 1.85]$ & .002 \\
\hline Enalapril & $1.15[0.84 ; 1.46]$ & $1.30[1.01 ; 1.60]$ & $1.42[1.15 ; 1.68]^{*}$ & $1.45[1.20 ; 1.71]^{*}$ & $1.59[1.34 ; 1.83]^{*}$ & $1.56[1.32 ; 1.81]^{*}$ & $1.52[1.29 ; 1.74]^{*}$ & $<.001$ \\
\hline Acetazolamide & $1.08[0.86 ; 1.29]$ & $1.25[1.01 ; 1.49]$ & $1.35[1.08 ; 1.63]$ & $1.29[1.07 ; 1.51]$ & $1.42[1.15 ; 1.69]^{*}$ & $1.44[1.17 ; 1.71]^{*}$ & $1.28[1.05 ; 1.52]$ & .001 \\
\hline \multicolumn{2}{|c|}{$p_{\text {interaction (pretreatment } \mathrm{x} \text { time) }}$} & \multicolumn{4}{|c|}{.535} & & & \\
\hline \multicolumn{9}{|c|}{$\operatorname{GFR}\left(\mathrm{ml} / \mathrm{min} / 1.73 \mathrm{~m}^{2}\right)$} \\
\hline Placebo & $98[90 ; 105]$ & $104[96 ; 111]$ & $98[91 ; 105]$ & $105[97 ; 113]^{*}$ & $101[92 ; 110]$ & $99[93 ; 106]$ & $100[91 ; 109]$ & .027 \\
\hline Allopurinol & $99[90 ; 108]$ & $102[93 ; 112]$ & $97[89 ; 105]$ & $103[94 ; 112]$ & $98[88 ; 108]$ & $99[91 ; 107]$ & $102[92 ; 111]$ & .132 \\
\hline Enalapril & $101[92 ; 110]$ & $104[94 ; 114]$ & $101[94 ; 108]$ & $104[96 ; 112]$ & $100[91 ; 109]$ & $102[94 ; 109]$ & $102[94 ; 110]$ & .568 \\
\hline Acetazolamide & $83[76 ; 89]^{\dagger}$ & $84[77 ; 92]$ & $77[70 ; 83]^{*}$ & $83[75 ; 91]$ & $83[76 ; 89]$ & $83[76 ; 89]$ & 85 [78;92] & .012 \\
\hline \multicolumn{2}{|c|}{$p_{\text {interaction (pretreatment } \mathrm{x} \text { time) }}$} & \multicolumn{4}{|c|}{.494} & & & \\
\hline \multicolumn{9}{|l|}{$\mathrm{C}_{\mathrm{H} 2 \mathrm{O}}(\mathrm{ml} / \mathrm{min})$} \\
\hline Placebo & $4.58[3.66 ; 5.50]$ & $2.87[2.08 ; 3.65]$ & $1.87[1.36 ; 2.38]^{*}$ & $2.27[1.46 ; 3.08]^{*}$ & $2.85[2.11 ; 3.59]$ & $2.64[2.00 ; 3.28]^{*}$ & $2.85[2.15 ; 3.55]^{*}$ & $<.001$ \\
\hline Allopurinol & $4.56[3.64 ; 5.48]$ & $3.05[2.02 ; 4.07]$ & $2.54[1.82 ; 3.27]^{*}$ & $2.04[0.98 ; 3.10]^{*}$ & $3.00[2.11 ; 3.90]$ & $3.06[2.19 ; 3.93]$ & $3.26[2.40 ; 4.12]$ & .011 \\
\hline Enalapril & $4.82[3.70 ; 5.94]$ & $3.57[2.48 ; 4.65]$ & $2.28[1.26 ; 3.29]^{*}$ & $2.28[1.48 ; 3.08]^{*}$ & $3.24[2.59 ; 3.89]$ & $2.23[1.26 ; 3.21]^{*}$ & $2.67[1.71 ; 3.63]$ & .001 \\
\hline Acetazolamide & $3.91[2.80 ; 5.01]$ & $1.99[1.12 ; 2.87]$ & $1.69[0.93 ; 2.46]$ & $1.63[0.87 ; 2.39]^{*}$ & $2.60[1.78 ; 3.42]$ & $2.67[1.78 ; 3.55]$ & $2.60[1.80 ; 3.40]$ & .004 \\
\hline \multicolumn{2}{|c|}{$p_{\text {interaction (pretreatment } \mathrm{x} \text { time) }}$} & \multicolumn{4}{|c|}{.682} & & & \\
\hline \multicolumn{9}{|l|}{ P-AVP (pg/ml) } \\
\hline Placebo & $0.32[0.25 ; 0.38]$ & & $0.25[0.20 ; 0.30]^{*}$ & & $0.27[0.21 ; 0.33]^{*}$ & & & .012 \\
\hline Allopurinol & $0.29[0.21 ; 0.36]$ & & $0.28[0.22 ; 0.33]$ & & $0.25[0.21 ; 0.29]$ & & & .414 \\
\hline Enalapril & $0.26[0.20 ; 0.33]$ & & $0.21[0.17 ; 0.26]$ & & $0.23[0.18 ; 0.28]$ & & & .213 \\
\hline Acetazolamide & $0.29[0.22 ; 0.36]$ & & $0.27[0.19 ; 0.35]$ & & $0.28[0.22 ; 0.34]$ & & & .770 \\
\hline \multicolumn{2}{|c|}{$p_{\text {interaction (pretreatment } \mathrm{x} \text { time) }}$} & \multicolumn{4}{|c|}{.630} & & & \\
\hline \multicolumn{9}{|l|}{ U-AQP2 (ng/min) } \\
\hline Placebo & $1.26[1.12 ; 1.41]$ & $1.25[1.06 ; 1.45]$ & $1.23[1.10 ; 1.35]$ & $1.18[1.04 ; 1.33]$ & $1.23[1.08 ; 1.39]$ & $1.19[1.06 ; 1.33]$ & $1.13[1.02 ; 1.23]$ & .167 \\
\hline Allopurinol & $1.45[1.27 ; 1.63]^{\dagger}$ & $1.37[1.26 ; 1.48]$ & $1.31[1.20 ; 1.42]$ & $1.34[1.21 ; 1.47]$ & $1.33[1.13 ; 1.54]$ & $1.31[1.20 ; 1.42]$ & $1.28[1.17 ; 1.39]$ & .080 \\
\hline Enalapril & $1.29[1.13 ; 1.44]$ & $1.23[1.09 ; 1.37]$ & $1.28[1.14 ; 1.42]$ & $1.26[1.13 ; 1.40]$ & $1.28[1.09 ; 1.46]$ & $1.33[1.18 ; 1.48]$ & $1.18[1.06 ; 1.31]$ & .131 \\
\hline Acetazolamide & $1.30[1.15 ; 1.45]$ & $1.26[1.08 ; 1.44]$ & $1.21[1.07 ; 1.36]$ & $1.19[1.04 ; 1.35]$ & $1.25[1.09 ; 1.41]$ & $1.26[1.08 ; 1.43]$ & $1.21[1.06 ; 1.37]$ & .363 \\
\hline \multicolumn{2}{|c|}{$p_{\text {interaction (pretreatment } \times \text { time) }}$} & \multicolumn{4}{|c|}{.590} & & & \\
\hline \multicolumn{9}{|l|}{ U-ENaCY (ng/min) } \\
\hline Placebo & $0.44(0.38 ; 0.51)$ & $0.44(0.33 ; 0.51)$ & $0.47(0.35 ; 0.54)$ & $0.45(0.36 ; 0.59)$ & $0.40(0.36 ; 0.57)$ & $0.43(0.36 ; 0.56)$ & $0.43(0.32 ; 0.46)$ & .331 \\
\hline Allopurinol & $0.43(0.40 ; 0.65)$ & $0.42(0.38 ; 0.54)$ & $0.39(0.34 ; 0.54)$ & $0.47(0.42 ; 0.61)$ & $0.43(0.30 ; 0.54)^{*}$ & $0.42(0.35 ; 0.51)$ & $0.39(0.34 ; 0.50)$ & .020 \\
\hline Enalapril & $0.44(0.40 ; 0.64)$ & $0.40(0.35 ; 0.49)$ & $0.39(0.34 ; 0.60)$ & $0.45(0.31 ; 0.53)$ & $0.39(0.36 ; 0.55)$ & $0.41(0.33 ; 0.57)$ & $0.45(0.40 ; 0.53)$ & .215 \\
\hline Acetazolamide & $0.68(0.48 ; 0.95)^{\dagger}$ & $0.57(0.42 ; 1.01)$ & $0.59(0.45 ; 0.94)$ & $0.53(0.48 ; 0.88)$ & $0.55(0.45 ; 0.93)$ & $0.71(0.53 ; 0.94)$ & $0.64(0.49 ; 0.89)$ & .561 \\
\hline
\end{tabular}

Effect of intravenous $\mathrm{NaNO}_{2}$ on fractional excretion of sodium $\left(\mathrm{FE}_{\mathrm{Na}}\right)$, GFR, free water clearance $\left(\mathrm{C}_{\mathrm{H} 2 \mathrm{O}}\right)$, urinary excretion rates of aquaporin-2 (AQP2) and $\gamma$-subunit of the epithelial sodium channel $(\mathrm{ENaC})$ in 14 healthy subjects and arginine vasopressine (AVP) in 16 healthy subjects after 4 days pretreatment with allopurinol, enalapril, acetazolamide, or placebo. Normal distributed data are presented as means with $95 \%$ confidence interval in brackets and non-parametric data as medians with 25th and 75th percentiles in parentheses. Statistics were performed using one-way repeated measures (RM) ANOVA for comparing over time and two-way RM ANOVA with time and pretreatment as within factors to test for interaction. Pairwise comparison where performed using Student's $t$-test. U-ENaC $Y$ were tested using Friedman test for comparing over time and Wilcoxon's signed rank test for pairwise comparison with placebo or baseline ${ }^{*} p<.05$ within group vs. baseline (Bonferroni), ${ }^{\dagger} p<.05$ vs. placebo at baseline 
Table 5 Effect of intravenous $\mathrm{NaNO}_{2}$ on brachial and central hemodynamics

\begin{tabular}{|c|c|c|c|}
\hline & Baseline value & Change from baseline to last hour of infusion & $p_{t \text {-test }}$ \\
\hline \multicolumn{4}{|c|}{ Brachial systolic BP (mmHg) } \\
\hline Placebo & $115(111 ; 119)$ & $-2.63(-4.41 ;-0.85)$ & .007 \\
\hline Allopurinol & $115(111 ; 119)$ & $-3.07(-5.12 ;-1.01)$ & .006 \\
\hline Enalapril & $110(107 ; 114)^{\dagger}$ & $-3.84(-5.32 ;-2.35)$ & $<.001$ \\
\hline Acetazolamide & $114(111 ; 118)$ & $-3.79(-5.85 ;-1.74)$ & .001 \\
\hline$p_{\text {RM ANOVA }}$ & & .272 & \\
\hline \multicolumn{4}{|c|}{ Brachial diastolic BP (mmHg) } \\
\hline Placebo & $60(57 ; 62)$ & $-1.50(-3.28 ; 0.28)$ & .093 \\
\hline Allopurinol & $60(56 ; 63)$ & $-1.22(-3.14 ; 0.70)$ & .196 \\
\hline Enalapril & $56(53 ; 59)^{\dagger}$ & $-1.18(-2.40 ; 0.03)$ & .054 \\
\hline Acetazolamide & $60(58 ; 63)$ & $-1.58(-3.04 ;-0.12)$ & .035 \\
\hline$p_{\text {RM ANOVA }}$ & & .923 & \\
\hline \multicolumn{4}{|c|}{ Brachial MAP (mmHg) } \\
\hline Placebo & $78(76 ; 81)$ & $-1.88(-3.39 ;-0.37)$ & .018 \\
\hline Allopurinol & $78(75 ; 81)$ & $-1.84(-3.63 ;-0.04)$ & .046 \\
\hline Enalapril & $74(72 ; 77)^{\dagger}$ & $-2.07(-3.28 ;-0.86)$. & .002 \\
\hline Acetazolamide & $78(76 ; 81)$ & $-2.32(-3.88 ;-0.76)$ & .006 \\
\hline$p_{\text {RM ANOVA }}$ & & .848 & \\
\hline \multicolumn{4}{|c|}{ Heart rate (beats per minute) } \\
\hline Placebo & $55(52 ; 58)$ & $3.37(1.95 ; 4.79)$ & $<.001$ \\
\hline Allopurinol & $55(52 ; 59)$ & $1.70(0.12 ; 3.28)^{\dagger}$ & .037 \\
\hline Enalapril & $56(52 ; 60)$ & $2.21(0.97 ; 3.45)$ & .002 \\
\hline Acetazolamide & $57(53 ; 61)$ & $1.30(0.11 ; 2.50)^{\dagger}$ & .035 \\
\hline$p_{\text {RM ANOVA }}$ & & .050 & \\
\hline \multicolumn{4}{|c|}{ Central systolic BP (mmHg) } \\
\hline Placebo & $98(89 ; 106)$ & $-1.38(-6.03 ; 3.26)$ & .528 \\
\hline Allopurinol & $99(91 ; 107)$ & $-4.51(-8.95 ;-0.07)$ & .047 \\
\hline Enalapril & $97(88 ; 106)$ & $-4.04(-8.13 ; 0.05)$ & .053 \\
\hline Acetazolamide & $101(90 ; 112)$ & $-2.69(-8.30 ; 2.91)$ & .320 \\
\hline$p_{\text {RM ANOVA }}$ & & .804 & \\
\hline
\end{tabular}

Effect of intravenous $\mathrm{NaNO}_{2}$ on heart rate, brachial and central blood pressure (BP) in 16 healthy subjects after 4 days pretreatment with allopurinol, enalapril, acetazolamide, or placebo. Data are means with $95 \%$ confidence interval in brackets. Baseline values are an average of measurements in the one-hour period prior to infusion. The baseline values were compared to an average of measurements during the last hour of $\mathrm{NaNO}_{2}$ infusion. Pairwise comparisons were performed using Student's $t$-test. One-way repeated measures (RM) ANOVA was used for comparison of effects between pretreatments ${ }^{+}: p<.05$ vs. placebo

Allopurinol reduced P-urate at baseline, as expected. While $\mathrm{NaNO}_{2}$ infusion lowered the brachial BP without active pretreatment, the reduction in central systolic BP (CSBP) was only significant after pretreatment with allopurinol. The cSBP reduction was not significantly different to the reduction after placebo pretreatment $(p=$ 0.539), partly owing to an inherent lesser precision in the tonometry based method [32]. Although the results should be interpreted cautiously, this could indicate a potentiation of the vasodilating effects of $\mathrm{NaNO}_{2}$. The remaining effects of $\mathrm{NaNO}_{2}$ were unaffected by pretreatment with allopurinol. The intact, or even potentiated, vasodilating effect of $\mathrm{NaNO}_{2}$ after allopurinol is in agreement with the findings by Dejam et al. of an augmented increase in forearm blood flow when $\mathrm{NaNO}_{2}$ and oxypurinol was co-infused [23]. A possible explanation could be a reduced scavenging of NO due to inhibition of xanthine oxidase-generated reactive oxygen species.

We observed an increase in renin concentration during $\mathrm{NaNO}_{2}$ infusion, but only after preceding stimulation of renin secretion by either enalapril or to a lesser extent acetazolamide. The interplay between $\mathrm{NO}$ and renin has been studied intensively since the late 1980's. Numerous in vitro studies have shown both inhibitory 
Table 6 Effect of intravenous $\mathrm{NaNO}_{2}$ on the renin-angiotensinaldosteron system

\begin{tabular}{|c|c|c|c|c|}
\hline & \multirow[t]{2}{*}{ Baseline } & \multicolumn{2}{|l|}{ Infusion } & \multirow{2}{*}{$\begin{array}{l}p_{\mathrm{RM}} \\
\text { ANOVA } \\
\text { (one-way) }\end{array}$} \\
\hline & & $60 \mathrm{~min}$ & $120 \mathrm{~min}$ & \\
\hline \multicolumn{5}{|l|}{ PRC (pg/ml) } \\
\hline Placebo & $9(6 ; 14)$ & $9(7 ; 16)$ & $9(8 ; 16)$ & .262 \\
\hline Allopurinol & $9(5 ; 12)$ & $9(6 ; 16)^{*}$ & $10(6 ; 14)$ & .024 \\
\hline Enalapril & $54(27 ; 89)^{+}$ & $72(40 ; 93)^{*}$ & $69(61 ; 95)^{*}$ & .014 \\
\hline Acetazolamide & $15(9 ; 20)^{\dagger}$ & $16(12 ; 23)$ & $18(12 ; 23)^{*}$ & .008 \\
\hline$p_{\text {interaction (pretrea }}$ & atment $x$ time) & .168 & & \\
\hline \multicolumn{5}{|l|}{ P-Angll (pg/ml) } \\
\hline Placebo & $16(12 ; 22)$ & $17(13 ; 20)$ & $14(11 ; 23)$ & .239 \\
\hline Allopurinol & $14(8 ; 19)^{\dagger}$ & $14(12 ; 21)$ & $13(10 ; 19)$ & .175 \\
\hline Enalapril & $11(6 ; 17)^{\dagger}$ & $13(8 ; 21)$ & $11(8 ; 21)$ & .189 \\
\hline Acetazolamide & $19(11 ; 34)$ & $20(14 ; 34)^{*}$ & $21(16 ; 35)^{*}$ & .001 \\
\hline$p_{\text {interaction (pretrea }}$ & atment $x$ time) & .160 & & \\
\hline \multicolumn{5}{|l|}{ P-Aldo (pmol/l) } \\
\hline Placebo & $128(98 ; 161)$ & $121(90 ; 155)$ & $106(79 ; 155)$ & .228 \\
\hline Allopurinol & $105(82 ; 158)$ & $98(64 ; 138)$ & $113(76 ; 147)$ & .967 \\
\hline Enalapril & $78(56 ; 106)$ & $77(54 ; 97)$ & $71(59 ; 117)$ & .511 \\
\hline Acetazolamide & $184(132 ; 281)^{\dagger}$ & $178(125 ; 308)$ & $230(110 ; 352)$ & .826 \\
\hline$p_{\text {interaction (pretrea }}$ & atment $x$ time) & .664 & & \\
\hline
\end{tabular}

Effect of intravenous $\mathrm{NaNO}_{2}$ on plasma concentrations of renin (PRC), angiotensin II (P-Angll), and aldosterone (P-Aldo) in 16 healthy subjects after 4 days pretreatment with allopurinol, enalapril, acetazolamide, or placebo. Data are medians with 25th and 75th percentiles in parentheses. After log transformation, statistics were performed using one-way repeated measures (RM) ANOVA for comparing over time and two-way RM ANOVA with time and pretreatment as within factors to test for interaction. Pairwise comparison with placebo or baseline where performed using Student's $t$-test after log transformation

${ }^{*} p<.05$ within group vs. baseline (Bonferroni), ${ }^{\dagger} p<.05$ vs. placebo at baseline

$[33,34]$, stimulatory $[35,36]$ and even biphasic effects [37] of NO or cGMP on renin secretion, while most in vivo studies agree on a stimulatory effect [38-40]. Our findings are in agreement with previous studies from our lab, showing a reduction of renin secretion after systemic NO inhibition in healthy subjects with activated renin system at baseline due to sodium restriction [41] or after angiotensin II receptor blockade [42]. A confounding effect of the BP reduction, being the strongest mediator of renin release, cannot be completely ruled out. However, $\mathrm{NaNO}_{2}$ infusion only increased renin when the basal renin concentration was elevated, after enalapril or acetazolamide, despite a comparable effect on the BP regardless of pretreatment. This pattern corresponds to a previous study by our group, showing no stimulatory effect on the RAAS when infusing BP reducing doses of $\mathrm{NaNO}_{2}$ after moderate sodium intake [25]. Interestingly, the BP lowering effect of $\mathrm{NaNO}_{2}$ was fully preserved after preceding BP reduction with enalapril, suggesting that the $\mathrm{BP}$ reducing mechanism of $\mathrm{NaNO}_{2}$ is independent of ACE activity.

Acetazolamide had a profound effect on multiple baseline values, e.g. 24-h sodium excretion, 24-h creatinine clearance, baseline GFR, and excretion rate of $\mathrm{ENaC \gamma}$. Previous studies have shown an acute diuretic and natriuretic effect $[43,44]$ in the proximal tubule, which waned off after a few days of continued treatment [44]. We detected an activation of the RAAS, with significantly elevated levels of renin and aldosterone, most likely caused by a decrease in extracellular volume and $\mathrm{pH}$. Aldosterone, being the primary regulator of $\mathrm{ENaC}$, was most probably responsible for the increase in $\mathrm{ENaC}$ and accompanying increase in sodium reabsorption. The decrease in GFR is well known and believed to be mediated by tubuloglomerular feedback [45]. The effects of $\mathrm{NaNO}_{2}$ infusion after acetazolamide did not differ from after placebo pretreatment.

We hypothesized 1) an attenuation of the effects of $\mathrm{NaNO}_{2}$ after inhibition of the nitrite reducing capabilities of XO with allopurinol as shown in rats [2-4], 2) an augmentation of the effects of $\mathrm{NaNO}_{2}$ after enalapril due to accumulation of bradykinin leading to up-regulation of eNOS [5, 6], and 3) an enhanced effect of $\mathrm{NaNO}_{2}$ after acetazolamide due to a stimulated enzymatic conversion of nitrite to NO by carbonic anhydrase [13, 14]. However, apart from a reduction of central systolic BP, which was only significant after allopurinol, we could not detect any consistent differences in the response to $\mathrm{NaNO}_{2}$ between the pretreatments. The results suggest that none of the studied pathways are essential to nitrite bioactivation.

The post-infusion reduction in U-cGMP and steady P-cGMP is consistent with our previous findings [25], but nevertheless puzzling and could indicate that the effects of $\mathrm{NaNO}_{2}$ might not be mediated by the NO-sGC-cGMP pathway. If the actions of $\mathrm{NaNO}_{2}$ under physiologic conditions are independent of NO production, it would explain why modulation of different enzyme systems with suspected nitrite reducing abilities failed to modify the effect. The differences in baseline parameters after each pretreatment were expected and can be ascribed to the fundamental effects of the enzyme inhibitors.

\section{Strengths and limitations}

The strengths of the present study lie in the design. It is a rigorously conducted, double-blinded, placebo-controlled, 4-way crossover study. The sodium intake is standardized and controlled. Adherence to the pretreatment was verified by baseline levels of P-renin, P-urate, and P-(vB)-total $\mathrm{CO}_{2}$ which reflected the pretreatment for all subjects without exception. Previous studies from our laboratory $[25,29,46,47]$ suggest a slightly natriuretic and anti-aquaretic effect of the supine and water loaded model, which 
might have contributed to the findings in the present study.

The dosage of $\mathrm{NaNO}_{2}$ relies on a previous dose-response study by our group [25]. Evaluated on the effects on $\mathrm{P}-\mathrm{NO}_{\mathrm{x}}, \mathrm{U}-\mathrm{NO}_{\mathrm{x}}$, sodium excretion and $\mathrm{BP}$, we believe to have achieved a relevant increase in nitrite bioavailability.

\section{Conclusion}

This study demonstrated a robust BP lowering, natriuretic and anti-aquaretic effect of intravenous $\mathrm{NaNO}_{2}$ regardless of preceding enzyme inhibition. The steady P-cGMP and post-infusion decrease in U-cGMP indicates little or no conversion of nitrite to NO. Thus the effect of $\mathrm{NaNO}_{2}$ may not be mediated by $\mathrm{NO}$ generation.

\begin{abstract}
Abbreviations
${ }^{51} \mathrm{Cr}$-EDTA: Chromium-51 labeled ethylenediamine tetraacetic acid; ACE: Angiotensin-converting enzyme; Aldo: Aldosterone; ANGll: Angiotensin II; AQP2: Aquaporin-2; AVP: Arginine vasopressin; BP: Blood pressure; CA: Carbonic anhydrase; CGMP: Guanosine 3',5'-cyclic monophosphate; $\mathrm{C}_{\mathrm{H} 2 \mathrm{O}}$ : Free water clearance; $\mathrm{C}_{\mathrm{Na}}$ : Sodium clearance; $\mathrm{C}_{\mathrm{osm}}$ : Osmolar clearance; CSBP: Central systolic blood pressure; ENaCY: $y$-subunit of the epithelial sodium channel; eNOS: Endothelial nitric oxide synthase; $\mathrm{FE}_{\mathrm{K}}$. Fractional excretion of potassium; $\mathrm{FE}_{\mathrm{Na}}$ : Fractional excretion of sodium; GFR: Glomerular filtration rate; MAP: Mean arterial pressure; $\mathrm{NaNO}_{2}$ : Sodium nitrite; $\mathrm{NO}$ : Nitric oxide; $\mathrm{NO}_{x}$ : Combined nitrite and nitrate; P-(vB)-total $\mathrm{CO}_{2}$ : Plasma total carbon dioxide in venous blood; PRC: Plasma renin concentration; RIA: Radioimmunoassay; sGC: Soluble guanylyl cyclase; UO: Urine output; UOR: Urine output rate; XO: Xanthine oxidase
\end{abstract}

\section{Acknowledgements}

We thank laboratory technicians Anne Mette Ravn, Kirsten Nygaard and Henriette Vorup Simonsen for skilled assistance in examining the subjects and performing laboratory analyses, Hanne Sahl and the kitchen staff for preparing the diet, and the Department of Clinical Biochemistry, Regional Hospital West Jutland, Denmark for assistance in routine analyses.

\section{Funding}

The study was conducted without external grants. All study drugs were paid for by our own lab.

\section{Availability of data and materials}

The datasets used and/or analysed during the current study and the trial protocol in Danish are available from the corresponding author on reasonable request.

\section{Authors' contributions}

$J B R$, EBP, and JNB designed the project; JBR performed the experiments and analyzed the data; JBR, EBP, and JNB interpreted the results; JBR drafted the manuscript; all authors revised, edited, and approved the manuscript.

\section{Ethics approval and consent to participate}

The study was approved by The Central Denmark Region Committees on Health Research Ethics, reference number 1-10-72-313-13 and the Danish Health and Medicines Authority, reference number 2013100160. The study was performed in accordance with the Declaration of Helsinki 2013. All subjects provided written informed consent. The experimental part of the study took place from November 28, 2014, to November 12, 2015. The trial was prospectively registered in The EU Clinical Trials Register, EudraCT 2013-003404-39.

\section{Consent for publication}

Not applicable

\section{Competing interests}

The authors declare that they have no competing interests.

\section{Publisher's Note}

Springer Nature remains neutral with regard to jurisdictional claims in published maps and institutional affiliations.

Received: 17 May 2017 Accepted: 3 September 2018

Published online: 21 September 2018

\section{References}

1. Kim-Shapiro DB, Gladwin MT. Mechanisms of nitrite bioactivation. Tanig Symp Brain Sci. 2014;38:58-68.

2. Casey DB, Badejo AM, Dhaliwal JS, Murthy SN, Hyman AL, Nossaman BD, Kadowitz PJ. Pulmonary vasodilator responses to sodium nitrite are mediated by an allopurinol-sensitive mechanism in the rat. Am J Physiol Heart Circ Physiol. 2009;296(2):H524-33.

3. Golwala NH, Hodenette C, Murthy SN, Nossaman BD, Kadowitz PJ. Vascular responses to nitrite are mediated by xanthine oxidoreductase and mitochondrial aldehyde dehydrogenase in the rat. Can J Physiol Pharmacol. 2009; 87(12):1095-101.

4. Ghosh SM, Kapil V, Fuentes-Calvo I, Bubb KJ, Pearl V, Milsom AB, Khambata R, Maleki-Toyserkani S, Yousuf M, Benjamin N, Webb AJ, Caulfield MJ, Hobbs AJ, Ahluwalia A. Enhanced vasodilator activity of nitrite in hypertension: critical role for erythrocytic xanthine oxidoreductase and translational potential. Hypertension. 2013;61(5):1091-102.

5. Zhao Y, Qiu Q, Mahdi F, Shariat-Madar Z, Rojkjaer R, Schmaier A. Assembly and activation of HK-PK complex on endothelial cells results in bradykinin liberation and NO formation. Am J Physiol Heart Circ Physiol. 2001;280(4): H1821-9.

6. Gauthier KM, Cepura CJ, Campbell WB. Ace inhibition enhances bradykinin relaxations through nitric oxide and b1 receptor activation in bovine coronary arteries. Biol Chem. 2013;394(9):1205-12.

7. Comini L, Bachetti T, Cargnoni A, Bastianon D, Gitti GL, Ceconi C, Ferrari R. Therapeutic modulation of the nitric oxide: all ace inhibitors are not equivalent. Pharmacol Res. 2007;56(1):42-8.

8. Kohno M, Yokokawa K, Minami M, Yasunari K, Maeda K, Kano H, Hanehira T, Yoshikawa J. Plasma levels of nitric oxide and related vasoactive factors following long-term treatment with angiotensin-converting enzyme inhibitor in patients with essential hypertension. Metab Clin Exp. 1999; 48(10):1256-9.

9. Kosenko E, Tikhonova L, Suslikov A, Kaminsky Y. Impacts of Lisinopril and Lisinopril plus simvastatin on erythrocyte and plasma arginase, nitrite, and nitrate in hypertensive patients. J Clin Pharmacol. 2012;52(1):102-9.

10. Kedziora-Kornatowska K, Kornatowski T, Bartosz G, Pawluk H, Czuczejko J, Kedziora J, Szadujkis-Szadurski L. Production of nitric oxide, lipid peroxidation and oxidase activity of ceruloplasmin in blood of elderly patients with primary hypertension. Effects of perindopril treatment. Aging Clin Exp Res. 2016;18(1):1-6.

11. Hornig B, Kohler C, Drexler H. Role of bradykinin in mediating vascular effects of angiotensin-converting enzyme inhibitors in humans. Circulation. 1997:95(5):1115-8.

12. Arcaro G, Zenere BM, Saggiani F, Zenti MG, Monauni T, Lechi A, Muggeo M, Bonadonna RC. ACE inhibitors improve endothelial function in type 1 diabetic patients with normal arterial pressure and microalbuminuria. Diabetes Care. 1999;22(9):1536-42

13. Kringelholt $S$, Simonsen $U$, Bek T. Dorzolamide-induced relaxation of intraocular porcine ciliary arteries in vitro depends on nitric oxide and the vascular endothelium. Curr Eye Res. 2012;37(12):1107-13.

14. Aamand R, Dalsgaard T, Jensen FB, Simonsen U, Roepstorff A, Fago A. Generation of nitric oxide from nitrite by carbonic anhydrase: a possible link between metabolic activity and vasodilation. Am J Physiol Heart Circ Physiol. 2009;297(6):H2068-74.

15. Aamand R, Ho Y, Dalsgaard T, Roepstorff A, Lund TE. Dietary nitrate facilitates an acetazolamide-induced increase in cerebral blood flow during visual stimulation. J Appl Physiol (1985). 2014;116(3):267-73.

16. Pedersen EB, Danielsen $\mathrm{H}$, Spencer ES. Effect of indapamide on renal plasma flow, glomerular filtration rate and arginine vasopressin in plasma in essential hypertension. Eur J Clin Pharmacol. 1984;26(5):543-7.

17. Pedersen EB, Eiskjaer H, Madsen B, Danielsen H, Egeblad M, Nielsen CB. Effect of captopril on renal extraction of renin, angiotensin II, atrial natriuretic peptide and vasopressin, and renal vein renin ratio in patients with arterial hypertension and unilateral renal artery disease. Nephrol Dial Transplant. 1993;8(10):1064-70. 
18. Pedersen RS, Bentzen H, Bech JN, Pedersen EB. Effect of water deprivation and hypertonic saline infusion on urinary $A Q P 2$ excretion in healthy humans. Am J Physiol Ren Physiol. 2001;280(5):F860-7.

19. Graffe CC, Bech JN, Pedersen EB. Effect of high and low sodium intake on urinary aquaporin-2 excretion in healthy humans. Am J Physiol Ren Physiol. 2012;302(2):F264-75

20. Al Therwani S, Malmberg MES, Rosenbaek JB, Bech JN, Pedersen EB. Effect of tolvaptan on renal handling of water and sodium, GFR and central hemodynamics in autosomal dominant polycystic kidney disease during inhibition of the nitric oxide system: a randomized, placebo-controlled, double blind, crossover study. BMC Nephrol. 2017;18:268.

21. Hager H, Kwon TH, Vinnikova AK, Masilamani S, Brooks HL, Frokiaer J, Knepper MA, Nielsen S. Immunocytochemical and immunoelectron microscopic localization of alpha-, beta-, and gamma-ENaC in rat kidney. Am J Physiol Ren Physiol. 2001;280(6):F1093-106.

22. Pluta RM, Oldfield EH, Bakhtian KD, Fathi AR, Smith RK, Devroom HL, Nahavandi M, Woo S, Figg WD, Lonser RR. Safety and feasibility of longterm intravenous sodium nitrite infusion in healthy volunteers. PLoS One. 2011;6(1):e14504.

23. Dejam A, Hunter CJ, Tremonti C, Pluta RM, Hon YY, Grimes G, Partovi K, Pelletier MM, Oldfield EH, Cannon RO III, Schechter AN, Gladwin MT. Nitrite infusion in humans and nonhuman primates: endocrine effects, pharmacokinetics, and tolerance formation. Circulation. 2007;116(16):1821-31.

24. Cosby K, Partovi KS, Crawford JH, Patel RP, Reiter CD, Martyr S, Yang BK, Waclawiw MA, Zalos G, Xu X, Huang KT, Shields H, Kim-Shapiro DB, Schechter AN, Cannon RO III, Gladwin MT. Nitrite reduction to nitric oxide by deoxyhemoglobin vasodilates the human circulation. Nat Med. 2003;9(12):1498-505.

25. Rosenbaek JB, Therwani SA, Jensen JM, Mose FH, Wandall-Frostholm C, Pedersen EB, Bech JN. Effect of sodium nitrite on renal function and sodium and water excretion and brachial and central blood pressure in healthy subjects: a dose-response study. Am J Physiol Ren Physiol. 2017;313(2):F378-87.

26. Kapil V, Milsom AB, Okorie M, Maleki-Toyserkani S, Akram F, Rehman F, Arghandawi S, Pearl V, Benjamin N, Loukogeorgakis S, Macallister R, Hobbs AJ, Webb AJ, Ahluwalia A. Inorganic nitrate supplementation lowers blood pressure in humans: role for nitrite-derived NO. Hypertension. 2010;56(2):274-81.

27. Ortiz PA, Garvin JL. Role of nitric oxide in the regulation of nephron transport. Am J Physiol Ren Physiol. 2002;282(5):F777-84.

28. Kanno K, Hirata Y, Emori T, Ohta K, Eguchi S, Imai T, Marumo F. L-arginine infusion induces hypotension and diuresis/natriuresis with concomitant increased urinary excretion of nitrite/nitrate and cyclic GMP in humans. Clin Exp Pharmacol Physiol. 1992;19(9):619-25.

29. Bech JN, Nielsen CB, Pedersen EB. Effects of systemic NO synthesis inhibition on RPF, GFR, UNa, and vasoactive hormones in healthy humans. Am J Phys. 1996:270(5 Pt 2):F845-51.

30. Bode-Boger SM, Boger RH, Galland A, Tsikas D, Frolich JC. L-arginine-induced vasodilation in healthy humans: pharmacokinetic-pharmacodynamic relationship. Br J Clin Pharmacol. 1998;46(5):489-97.

31. Omar SA, Fok H, Tilgner KD, Nair A, Hunt J, Jiang B, Taylor P, Chowienczyk P, Webb AJ. Paradoxical normoxia-dependent selective actions of inorganic nitrite in human muscular conduit arteries and related selective actions on central blood pressures. Circulation. 2015;131(4):381-9.

32. Cheng HM, Lang D, Tufanaru C, Pearson A. Measurement accuracy of noninvasively obtained central blood pressure by applanation tonometry: a systematic review and meta-analysis. Int J Cardiol. 2013;167(5):1867-76.

33. Vidal MJ, Romero JC, Vanhoutte PM. Endothelium-derived relaxing factor inhibits renin release. Eur J Pharmacol. 1988;149(3):401-2.

34. Beierwaltes $\mathrm{WH}$, Carretero OA. Nonprostanoid endothelium-derived factors inhibit renin release. Hypertension. 1992;19(2 Suppl):68-73.

35. Hackenthal $E$, Taugner R. Hormonal signals and intracellular messengers for renin secretion. Mol Cell Endocrinol. 1986;47(1-2):1-12.

36. Münter $\mathrm{K}$, Hackenthal $\mathrm{E}$. The participation of the endothelium in the control of renin release. J Hypertens. 1991;9(Supplement 6):S238.

37. Schricker K, Kurtz A. Liberators of NO exert a dual effect on renin secretion from isolated mouse renal juxtaglomerular cells. Am J Phys. 1993;265(2 Pt 2):F180-6.

38. Persson PB, Baumann JE, Ehmke H, Hackenthal E, Kirchheim HR, Nafz B. Endothelium-derived NO stimulates pressure-dependent renin release in conscious dogs. Am J Phys. 1993;264(6 Pt 2):F943-7.

39. Johnson $\mathrm{RA}$, Freeman $\mathrm{RH}$. Renin release in rats during blockade of nitric oxide synthesis. Am J Phys. 1994;266(6 Pt 2):R1723-9.
40. Beierwaltes WH. cGMP stimulates renin secretion in vivo by inhibiting phosphodiesterase-3. Am J Physiol Ren Physiol. 2006;290(6):F1376-81.

41. Bech JN, Nielsen CB, Ivarsen P, Jensen KT, Pedersen EB. Dietary sodium affects systemic and renal hemodynamic response to $\mathrm{NO}$ inhibition in healthy humans. Am J Physiol Ren Physiol. 1998;274(5 Pt 2):F914-23.

42. Bech JN, Svendsen KB, Nielsen CB, Pedersen EB. The systemic and renal response to $\mathrm{NO}$ inhibition is not modified by angiotensin-II-receptor blockade in healthy humans. Nephrol Dial Transplant. 1999;14(3):641-7.

43. Skøtt P, Hommel E, Bruun NE, Arnold-Larsen S, Parving HH. The acute effect of acetazolamide on glomerular filtration rate and proximal tubular reabsorption of sodium and water in normal man. Scand J Clin Lab Invest. 1989;49(6):583-7.

44. Skøtt P, Hommel E, Bruun NE, Arnold-Larsen S, Parving HH. Effects of acetazolamide on kidney function in type 1 (insulin-dependent) diabetic patients with diabetic nephropathy. Diabetologia. 1988;31(11):806-10.

45. Persson A, Wright FS. Evidence for feedback mediated reduction of glomerular filtration rate during infusion of acetazolamide. Acta Physiol Scand. 1982;114(1):1-7.

46. Larsen T, Mose FH, Bech JN, Pedersen EB. Effect of nitric oxide inhibition on blood pressure and renal sodium handling: a dose-response study in healthy man. Clin Exp Hypertens. 2012;34(8):567-74.

47. Lauridsen TG, Vase $H$, Bech JN, Nielsen S, Pedersen EB. Direct effect of methylprednisolone on renal sodium and water transport via the principal cells in the kidney. Eur J Endocrinol. 2010;162(5):961-9.
Ready to submit your research? Choose BMC and benefit from:

- fast, convenient online submission

- thorough peer review by experienced researchers in your field

- rapid publication on acceptance

- support for research data, including large and complex data types

- gold Open Access which fosters wider collaboration and increased citations

- maximum visibility for your research: over 100M website views per year

At BMC, research is always in progress.

Learn more biomedcentral.com/submissions 